\title{
PERAN MOTIVASI SEBAGAI MEDIASI TERHADAP HUBUNGAN PENGAWASAN DAN KINERJA KARYAWAN (Studi Kasus Pada PT. Asuransi Central Asia Cab. Jambi)
}

\author{
Ubaidillah
}

Fakultas Ekonomi Universitas Batanghari, Jambi, Indonesia

\begin{abstract}
This study aims to look at the effect of supervision on employee performance at PT.Asuransi Central Asia, Tbk Jambi Branch, and the role of motivation as a mediating variable on the relationship between supervision and performance. The data in this study uses qualitative data by distributing questionnaires that include alternative answers that have been provided to respondents. After the data is collected, it is then analyzed to answer the formulation of the problem using the path analysis method. The results of this study indicate that supervision influences employee performance either directly or through motivation as a mediating variable.
\end{abstract}

Keyword: motivation, mediation, supervision, performance

\section{PENDAHULUAN}

Sumber daya manusia memegang peranan yang paling penting pada suatu organisasi, untuk mencapai tujuan organisasi dibutuhkan bakat atau kemampuan, tenaga dan kreatitas dari sumber daya manusia. Sebaliknya sumber daya manusia juga mempunyai berbagai macam kebutuhan yang ingin dipenuhi. Keinginan untuk memenuhi kebutuhan inilah yang dipandang sebagai pendorong atau penggerak bagi seseorang untuk melakukan sesuatu, termasuk untuk bekerja.

Manajemen sumber daya manusia secara opersional meliputi penarikan, seleksi, pengembangan, penggunaan dan pemeliharaan sumber daya manusia di dalam suatu organisasi maupun perusahaan sering kali terjadi kesalahan dalam melakukan pekerjaan, kesalahan dan penyimpangan kegiatan kerja yang dilakukan oleh karyawan tersebut dapat merugikan perusahaan maka dari itu diperlukannya pengawasan karena pada dasarnya manusia akan melakukan tindakan negatif bila tidak diawasi oleh pimpinan saat bekerja atau melakukan kegiatan dalam perusahaan tersebut. pentingnya pengawasan dalam sebuah organisasi perusahaan, menjadikan hal ini dianggap sebagai suatu hal yang serius.
Dalam sebuah organisasi, motivasi sangat penting dalam mempengaruhi kinerja pegawai. Karena motivasi adalah suatu faktor yang mendorong seseorang untuk melakukan suatu aktivitas tertentu, oleh karena itu motivasi sering diartikan sebagai faktor pendorong seseorang. Kurangnya perhatian ataupun motivasi yang diberikan pimpinan terhadap karyawan, hal ini mempengaruhi lancarnya kinerja karyawan yang dibebankan kepadanya

Objek dalam penelitian ini yaitu PT. Asuransi Central Asia, Tbk Cab. Jambi dan yang menjadi permasalahan dalam penelitian ini yaitu bagaimanakah pengaruh dari pengawasan dalam meningkatkan kinerja pegawai melalui motivasi sebagai variabel mediasi.

\section{Kajian Teori \\ Kinerja}

Dalam beberapa literatur, istilah kinerja dikenal pula dengan istilah prestasi kerja, dimana prestasi kerja ini merupakan proses yang digunakan organisasi untuk mengevaluasi pelaksanaan kerja individu. Adapun output yang dihasilkan dapat berupa fisik maupun non fisik (Gomes 1995). Untuk mengetahui kinerja pegawai, maka perlu diadakan penilaian terhadap kinerja itu sendiri, dari penilaian itu dapat 
diketahui apakah kinerja yang dihasilkan oleh pegawai memenuhi standar atau tidak.

Menurut Sedarmayanti (2007) mengutarakan bahwa standar kinerja perlu dirumuskan guna dijadikan tolok ukur dalam mengadakan perbandingan antara apa yang telah dilakukan dengan apa yang diharapkan, kaitannya dengan pekerjaan atau jabatan yang telah dipercayakan kepada seseorang.

Mathis dan Jackson (2006), kineja (performance) pada dasarnya adalah apa yang dilakukan atau tidak dilakukan oleh karyawan. Kinerja karyawan yang umum untuk kebanyakan pekerjaan meliputi beberapa unsur yaitu: kualitas dari hasil; kuantitas dari hasil; ketepatan waktu dari hasil; kehadiran; kemampuan untuk bekerja sama.

\section{Motivasi}

Hasibuan (2001) menjelaskann bahwa motivasi adalah pemberian daya penggerak yang menciptakan kegairahan kerja seseorang, agar mau bekerja sama, bekerja efektif dan terintegrasi dengan segala daya upayanya untuk mencapai kepuasan, sedangkan Mangkunegara (2013), mendefinisikan sebagai suatu kecendrungan untuk beraktifitas, dimulai dari dorongan dalam diri dan diakhiri dengan penyesuaian diri, penyesuaian diri dikatakan untuk memuaskan.

Indikator motivasi kerja dalam penelitian ini adalah: upah yang adil dan layak; kesempatan untuk maju; kondisi kerja yang baik; loyalitas pimpinan terhadap karyawan; tunjangan; promosi (Mangkunegara 2013).

\section{Pengawasan}

Pengawasan dapat didefinisikan sebagai cara suatu organisasi mewujudkan kinerja yang efektif dan efesien, serta lebih jauh mendukung terwujudnya visi dan misi organisasi. Pengawasan adalah sebagai proses untuk menjamin bahwa tujuantujuan organisasi dan manajemen tercapai (Handoko, 2003).
Menurut Handoko (2003) indikator dari pengawasan yaitu : akurat; tepat waktu; objektif dan menyeluruh; terpusat pada titik-titik pengawasan strategi; realistik secara ekonomis; realistik secara organisasional; terkoordinasi dengan aliran kerja organisasi; fleksible; bersifat sebagai petunjuk dan operasional; diterima para anggota.

\section{Hipotesis}

Adapun hipotesis yang diajukan pada penlitian ini yaitu

1. Pengawasan berpengaruh positif dan signifikan terhadap motivasi karyawan

2. Motivasi berpengaruh secara signifikan terhadap kinerja karyawan

3. Motivasi memediasi secara positif dan signifikan terhadap hubungan antara pengawasan dan kinerja karyawan

\section{METODE PENELITIAN}

Penelitian ini adalah berjenis penelitian survei untuk tujuan eksplanatif dan eksploratif. Tujuan eksplanatif yaitu untuk menjelaskan jalinan hubungan di antara variabel-variabel utama, yaitu variabel pengawasan sebagai variabel dependen dan dua variabel independen berupa motivasi dan kinerja karyawan. Sampel pada penelitian ini yaitu seluruh karyawan pada PT. Asuransi Central Asia Cab. Jambi, data dikumpulkan melalui instrumen kuesioner penelitian dan kemudian diolah dengan menggunakan metode analisis jalur (Path Analysis)

\section{HASIL DAN PEMBAHASAN Realibilitas Konstruk}

Berdasarkan hasil pengolahan data dengan menggunakan program statistik jenis SPSS diperoleh angka-angka reliabilitas untuk masing-masing konstruk seperti pada tabel berikut ini.

Tabel 1. Hasil Perhitungan Reliabilitas terhadap Variabel-variabel Penelitian

Variabel Jumlah Indikator Nilai Cronbach $\operatorname{Alpha(\alpha )}$ Keterangan

\begin{tabular}{ccc}
\hline Variabel & Cronbach Alpha & Keterangan \\
\hline Pengawasan & 0,82 & Reliabel \\
Motivasi & 0,75 & Reliabel
\end{tabular}


Kinerja 0,88 Reliabel

\section{Model Penelitian}

Model mediasi untuk penelitian ini dengan menggunakan koefisien jalur standardize adalah seperti disajikan pada gambar berikut ini

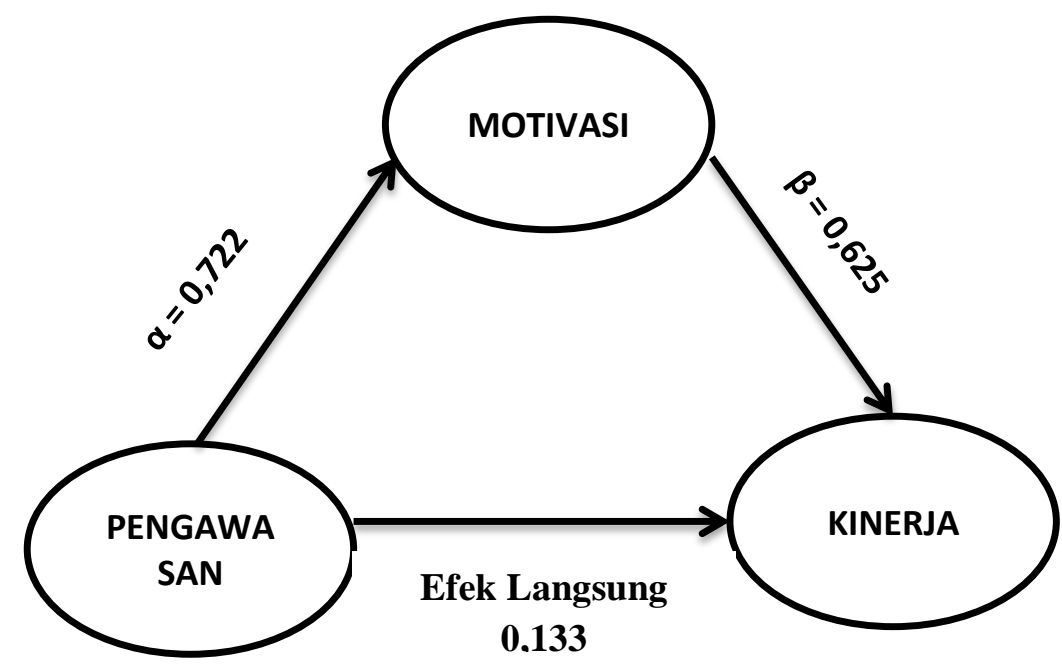

Gambar di atas memperlihatkan koefisien-koefisien jalur dari pengawasan terhadap kinerja melalui motivasi sebagai variabel mediasi dengan tingkat signifikansi dibawah 0,05. Efek langsung pengawasan terhadap kinerja adalah sebesar 0,133 dengan tingkat signifansi 0,04, pengaruh pengawasan terhadap motivasi sebesar 0,722 dengan tingkat signifikansi 0,01 , sedangkan pengaruh motivasi terhadap kinerja sebesar 0,625 dengan tingkat signifikansi 0,00 .

Untuk menguji signifikansi dari keberadaan mediasi di dalam model yang dihipotesiskan maka digunakan software yang dikembangkan oleh Sobel, yang lebih dikenal sebagai Sobel Test. Dari hasil perhitungan sobel test didapatkan angka sebesar 2,56 dengan tinglkat signifikansi sebesar 0,5 , yang berarti motivasi dapat memediasi hubungan antara pengawasan dan kinerja karyawan pada PT. Asuransi Central Asia Cab. Jambi, Tbk.

\section{SIMPULAN}

Dari hasil dan pembahasan di atas dapat dilihat bahwa pengawasan berpengaruh secara positif dan signifikan terhadap kinerja karyawan pada PT. Asuransi Central Asia,Tbk Cabang Jambi melalui motivasi sebagai variabel mediasi, hal ini dapat diartikan bahwa semakin meningkatnya pengawasan maka akan semakin meningkat pula motivasi yang nantinya akan berimplikasi terhadap kinerja karyawan pada PT. Asuransi Central Asia Cab. Jambi, Tbk

Dikarenakan begitu besarnya pengaruh pengawasan terhadap motivasi dan kinerja karyawan pada PT. Asuransi Central Asia,Tbk Cabang Jambi, maka perusahaan harua terus meningkatkan pengawasan yang intensif serta dapat pula memberikan motivasi terhadap karyawan sehingga dapat meningkatkan kinerja organisasi dan dapat mencapai tujuan tujuan yang telah ditetapkan oleh organisasi.

\section{DAFTAR PUSTAKA}

Gomes, Faustino Cardoso, 1995. Manajemen Sumber Daya Manusia, Yogyakarta: CV. Andi Offset

Handoko, T. Hani, 2003, Manajemen, Edisi 2, Penerbit BPFE, Yogyakarta

Hasibuan, Malayu. 2001. Manajemen Sumber Daya Manusia: Pengertian Dasar, Pengertian, dan Masalah. Jakarta: PT. Toko Gunung Agung 
Mathis, R.L. \& J.H. Jackson. 2006. Human Resource Management: Manajemen Sumber Daya Manusia. Terjemahan Dian Angelia. Jakarta: Salemba Empat

Mangkunegara, AA. Anwar Prabu, 2013, Manajemen Sumber Daya Manusia Perusahaan, Remaja Rosdakarya, Bandung.

Sedarmayanti, 2007, Sumber Daya Manusia dan Produktivitas Kerja, Bandung, Penerbit Mandar Maju 